The other apparatus (6 and 7 ) is likewise simple and is designed to secure rapid measurement of the extent and direction of errors in the localization of cutaneous sensations.

\title{
REFERENCES
}

I. Chinaglia, L. Riempimento soggettivo di spazi vuoti nel campo delle sensazion cutanee. Rio. di Piscol., 1912, 8, 133-135.

2. Cook, H. D., \& FREY, M. v. Der Einfluss der Reizstärke auf den Wert der simultanen Raumschwelle der Haut. Zsch. f. Biol., 1911, 56, 537-573.

3. Ponzo, M. Recherches sur la localisation des sensations tactiles et des sensations dolorifiques. Arch. ital. de biol., 1911, 55, I-14.

4. Ponzo, M. Sur un nouveau compas pour mesurer les perceptions d'espace dans le champ des sensations cutanées. Arch. ital. de biol., 1911, 56, 139-144.

5. Ponzo, M. Ueber einen neuen Zirkel für die Bestimmung der simultanen Raumschwellen der Körperhaut. Arch.f.d. ges. Psychol., I9I I, 22, 390-394.

6. Ponzo, M. Sur un appareil pour la détermination facile et précise de la grandeur et la direction des erreurs de localisation dans le champ des sensations cutanées. Atch. ital. de biol., 1911, 56, 148-150.

7. Ponzo, M. Ueber einen Apparat zur Bestimmung der beim Lokalisieren von Hautempfindungen begangenen Fehler und deren Richtungen (Dermolokalimeter). Arch.f.d.ges. Psychol., 1911, 22, 105-107.

\section{SPACE ILLUSIONS}

\section{BY PROFESSOR HARVEY CARR}

\section{University of Chicago}

Ponzo in his two papers $(5,6)$ gives a restatement of some facts and apparatus which he has previously published in other journals, and which were reviewed in last year's report. Schmidt (7) gives a translation and commentary of a lately discovered Latin manuscript of Kant which consists mainly of notes, partly disconnected, used in a disputation. His various arguments, possessing but little psychological interest, are directed against the thesis of his opponent that the sense illusions and the dominance of the perceptual furnish the clue for the interpretation of much in the literature of early peoples.

Benussi's work (I) on solidity reversals of ambiguous figures was instigated by that of Becher and de Boer reported last year. The time of cognition reactions for the perception of solidity was taken for one observer for four positions of a cube. One type of solidity prevailed for each position. The reaction times varied greatly for the four positions. Practice decreased the times but in an irregular manner. Tachistoscopic exposures with many subjects for two intervals demonstrated that the frequency of the solidity perception 
was related to the length of the exposure, though generalizations are regarded as unsafe because of the presence of after-images. The most important facts are those derived from introspective observations: Sides differ in apparent size as well as apparent depth, though there is no correlation between the two, as reversals in depth occurred without any change in relative size. The solidity often appears to have a reference to a vertical plane as its base and not to a horizontal plane. Lines non-essential to solidity were often unnoticed. The eye movement and fixation hypotheses are discarded; motives of "Bodenständigkeit" are not always available; reproductive processes are not the exclusive factor, as practice does not decrease the reaction times regularly. Certain arrangements of plane lines are associated with a definite type of solidity, and reversals are due to the fluctuating dominance of these plane patterns.

Hofmann (2) in studying the relation between the apparent directions of the horizontal and vertical noted that he invariably gave: them both an anti-clockwise twist from their true positions. $\mathrm{He}$ normally holds his head inclined to the right and his tests indicate that this head inclination is due to an asymmetrical ocular tension, and that this tension is responsible for the deviation of the apparent direction of the two lines.

The article of Piéron (4) consists mainly of an excellent digest of the literature on the Müller-Lyer illusion. His tests are supplementary to previous experimentation. He maintains that the illusion is based upon a double mechanism, i. e., two theories are applicable. In momentary exposures, estimation is inaccurate and the illusion persists with practice; these facts are explicable in terms of the Einthoven conception. With prolonged exposure, eye movements are regarded as the effective factor.

Tichý (9) worked with the Poggendorff illusion on eight subjects using a variety of methods. His results disagree with Wundt's statement that a reversal of the illusion occurs for the horizontal position when the intervening space is composed of a series of vertical lines. He found that the "continuation line" is invariably located in the direction of the obtuse angle. There is not even a diminution of the illusion for the horizontal position. The illusion does not depend upon binocular vision, freedom or fixity of fixation, knowledge or ignorance. Its size varies directly with the size of the intervening space and inversely with the size of the angle. The facts lead him to reject the Wundtian motives and to accept an explanation in terms of a tendency of the eyes to cross the intervening space by as short a line as possible. 
Lewis (3) and Valentine (ro) continue the Cambridge work with the tachistoscopic projection method. Valentine attacks the theories of Lipps and Külpe as to the vertical-horizontal illusion. The indefiniteness of the Lippsian concept does not render it subject to conclusive experimental disproof and the author does not regard his tests as final. In opposition to the theory of Külpe that the contour of the visual field produces the illusion by contrast, he finds that the value of the illusion is greater for monocular vision where there is less disparity between the vertical and horizontal diameters of the visual field. Significant facts noted are: Practice increased the illusion with three subjects; the value of the illusion differs for the two eyes; and there is some indication that a maximum value is correlated with a definite length of line. No theory is advanced. Lewis worked with filled and unfilled visual extents and found: The illusion is largest with momentary exposure; its size does not vary directly with the length of the line; there is a maximal effect with a certain degree of filling; prolonged exposure and a minimum of filling produce underestimation; prolonged exposure and unsymmetrical filling diminish the illusion; and practice destroys the effect very quickly. The effective factors are thus duration of exposure, practice, amount and arrangement and nature of the filling. The Wundtian, Hering and all physiological theories are discarded and an appeal is made to the judgmental aspect of perception.

Schubotz (8) seems to be mainly interested in a comparison of monocular and binocular space. He has constructed a very complicated and interesting apparatus which will not allow of a brief description. He deals with four problems. (I) In the verticalhorizontal illusion as exemplified in the square, he finds no correlation between its size and the distance from the observer with varying convergence. With fixation beyond the square, overestimation increases with decrease of depth. Its size varies somewhat directly with the size of the square. There was no maximum value as found by Valentine. He agrees with Valentine that monocular vision gives the largest illusion. (2) By a transparent. mirror he superimposed extents monocularly perceived upon those binocularly seen. There was no difference with prolonged exposure. With some conditions of observation, a slight binocular underestimation was correlated with a nearer depth location. (3) He determined the form of apparent straight lines extending in the third dimensional direction. Such apparent straight lines are really straight when located at the height of the eyes. Lines above and below the eyes are curved in the middle 
down and up respectively. The construction of two such lines makes the curvature greater and opposite to that which would occur for one line. The results are similar with monocular vision. (4) $\mathrm{He}$ attempted to determine the scope or range of binocular unitary vision. The near range is less than the far range. The lateral and the depth ranges are intimately connected. The depth range is greater for points adjacent to the median line; it is increased by a multiplicity of objects in the field, and decreased when the fixation is lateral to the median plane.

\section{REFERENCES}

1, Benussi, V. Ueber die Motive der Scheinkörperlichkeit bei umkehrbaren Zeichnungen. Arch. f. d. ges. Psychol., I9r I, 20, 363-396.

2. Hofmann, F. B. Der Einfluss schräger Konturen auf die scheinbare Horizontale und Vertikale. Ber. IV. Kongress $f$. exper. Psychol., 1911, 236-239.

3. LEwis, E. O. The Illusion of Filled and Unfilled Space. Brit. J. of Psychol., $1912,5,36-50$.

4. Préron, H. L'illusion de Müller-Lyer et son double mécanisme. Reo. phil., 19II, 7I, 245-284.

5. Ponzo, M. Sur une nouvelle illusion dépendant du croisement des doigts. Arch. ital. de biol., 1911, 56, 127-128.

6. Ponzo, M. Sur quelque illusions dans le champ des sensations tactiles. Arch.ital. de biol., 1911, 55, 20-34.

7. Schmid, B. A. Eine bisher unbekannte lateinische Rede Kants über Sinnestäuschung und poetische Fiktion. Kantstud., I9I I, 16, 5-21.

8. Schuвотz, F. Beiträge zur Kenntnis des Sehraumes auf Grund der Erfahrung. Arch. f. d. ges. Psychol., 1911, 20, 101-149.

9. Ticrý, G. Ueber eine vermeintliche optische Täuschung. Zsch f. Psychol., $1912,60,267-279$.

ro. Valentine, C. W. Psychological Theories of the Horizontal-Vertical Illusion. Brit. J. of Psychol., 1912, 5, 8-35.

\section{VALUES}

\section{BY PROFESSOR WILBUR M. URBAN}

\section{Trinity College}

The history of Value-theory for I9II is to be found more in its enrichment of other fields of inquiry than in any noteworthy additions to the psychological and technical side of the subject. The "trail" leads one to chapters on the Consciousness of Value in books on religion (7), to studies of the psychology of value in books on economics (I) and indeed, as will appear, to strictly philosophical treatises themselves. As a preliminary to this review, however, the pronouncement of that veteran of the subject, Meinong (10), on 